medRxiv preprint doi: https://doi.org/10.1101/2020.10.01.20205229; this version posted October 2, 2020. The copyright holder for this preprint (which was not certified by peer review) is the author/funder, who has granted medRxiv a license to display the preprint in perpetuity.

It is made available under a CC-BY-ND 4.0 International license .

1 Cardiovascular risk factors are independently associated with COVID-19 mortality: a

\title{
2 prospective cohort study
}

3 Authors: Didier Collard MD ${ }^{1 *}$, Nick S. Nurmohamed MD ${ }^{1,2^{*}}$, Yannick Kaiser MD ${ }^{1^{*}}$, Laurens

4 F. Reeskamp MD ${ }^{1}$, Tom Dormans MD PhD ${ }^{3}$, Hazra Moeniralam MD PhD ${ }^{4}$, Suat Simsek MD

$5 \mathrm{PhD}^{5}$, Renée A. Douma MD PhD ${ }^{6}$, Annet Eerens ${ }^{7}$, Auke C. Reidinga $\mathrm{MD}^{8}$, Paul Elbers MD

$6 \mathrm{PhD}^{9}$, Martijn Beudel MD PhD ${ }^{10}$, Liffert Vogt MD PhD ${ }^{11}$, Erik S.G. Stroes MD PhD ${ }^{1}$, Bert-

7 Jan $\mathrm{H}$. van den Born MD $\mathrm{PhD}^{1,12}$

*These authors contributed equally to this work

\section{Affiliations}

${ }^{1}$ Amsterdam UMC, University of Amsterdam, Department of Vascular Medicine, Amsterdam Cardiovascular Sciences, Amsterdam, the Netherlands

${ }^{2}$ Amsterdam UMC, Vrije Universiteit Amsterdam, Department of Cardiology, Amsterdam Cardiovascular Sciences, Amsterdam, the Netherlands

${ }^{3}$ Zuyderland Medisch Centrum, Department of Intensive Care, Sittard-Geleen, the Netherlands

${ }^{4}$ St. Antonius Hospital, Department of Internal Medicine, Nieuwegein, the Netherlands

${ }^{5}$ Northwest Clinics, Department of Internal Medicine, Alkmaar, The Netherlands

${ }^{6}$ Flevohospital, Department of Internal Medicine, Almere, The Netherlands

${ }^{7}$ Treant Healthcare Group, Department of Oncology, Hoogeveen, The Netherlands

${ }^{8}$ Martini Hospital, Intensive Care Unit, Groningen, The Netherlands

${ }^{9}$ Amsterdam UMC, Vrije Universiteit Amsterdam, Department of Intensive Care, Amsterdam Amsterdam, the Netherlands

${ }^{10}$ Amsterdam UMC, University of Amsterdam, Department of Neurology, Amsterdam Neuroscience Institute, Amsterdam, the Netherlands

${ }^{11}$ Amsterdam UMC, University of Amsterdam, Department of Nephrology, Amsterdam Cardiovascular Sciences, Amsterdam, the Netherlands

${ }^{12}$ Amsterdam UMC, University of Amsterdam, Department of Public Health, Amsterdam, the Netherlands

Keywords: COVID-19, SARS-CoV-2, CVD, hypertension, diabetes, mortality, ICUadmission

Word count: 3562 (manuscript, including references), 291 (abstract)

Figures: tables: 1, figures: 1, supplementary figures: 1, supplementary tables: 2

\section{Address for correspondence}

Dr. Bert-Jan H. van den Born 
medRxiv preprint doi: https://doi.org/10.1101/2020.10.01.20205229; this version posted October 2, 2020. The copyright holder for this preprint (which was not certified by peer review) is the author/funder, who has granted medRxiv a license to display the preprint in perpetuity.

It is made available under a CC-BY-ND 4.0 International license .

\section{Abstract}

2 Objectives: Recent reports suggest a high prevalence of hypertension and diabetes in

3 COVID-19 patients, but the role of cardiovascular disease (CVD) risk factors in the clinical

4 course of COVID-19 is unknown. We evaluated the time-to-event relationship between

5 hypertension, dyslipidemia, diabetes, and COVID-19 outcomes.

6 Design: We analyzed data from the prospective Dutch COVID-PREDICT cohort, an ongoing

7 prospective study of patients admitted for COVID-19 infection.

8 Setting: Patients from 8 participating hospitals, including two university hospitals from the

9 COVID-PREDICT cohort were included.

10 Participants: Admitted, adult patients with a positive COVID-19 polymerase chain reaction

11 (PCR) or high suspicion based on CT-imaging of the thorax. Patients were followed for major

12 outcomes during hospitalization. CVD risk factors were established via home medication lists

13 and divided in antihypertensives, lipid lowering therapy, and antidiabetics.

14 Primary and secondary outcomes measures: The primary outcome was mortality during

15 the first 21 days following admission, secondary outcomes consisted of ICU-admission and

16 ICU-mortality. Kaplan-Meier and Cox-regression analyses were used to determine the

17 association with CVD risk factors.

18 Results: We included 1604 patients with a mean age of $66 \pm 15$ of whom $60.5 \%$ were men.

19 Antihypertensives, lipid lowering therapy, and antidiabetics were used by $45 \%, 34.7 \%$, and

$2022.1 \%$ of patients. After adjustment for age and sex, the presence of $\geq 2$ risk factors was

21 associated with increased mortality risk (HR 1.52, 95\%CI 1.15-2.02), but not with ICU-

22 admission. Moreover, the use of $\geq 2$ antidiabetics and $\geq 2$ antihypertensives was associated

23 with mortality independent of age and sex with HRs of respectively 2.09 (95\%CI 1.55-2.80)

24 and $1.46(95 \%$ CI 1.11-1.91). 
medRxiv preprint doi: https://doi.org/10.1101/2020.10.01.20205229; this version posted October 2, 2020. The copyright holder for this preprint

(which was not certified by peer review) is the author/funder, who has granted medRxiv a license to display the preprint in perpetuity.

It is made available under a CC-BY-ND 4.0 International license.

1 Conclusions: The accumulation of hypertension, dyslipidemia and diabetes leads to a

2 stepwise increased risk for short-term mortality in hospitalized COVID-19 patients

3 independent of age and sex. Further studies investigating how these risk factors

4 disproportionately affect COVID-19 patients are warranted.

5

$6 \quad$ Strengths and limitations of this study

7 - While previous data reported a high prevalence of CVD risk factors in COVID-19

8 patients, this study investigated whether diabetes, dyslipidemia and hypertension

$9 \quad$ predict adverse outcomes.

10 - This study is limited by the use of medication as surrogate for cardiovascular risk

11 factors

12 - The causality of the investigated risk factors remains to be addressed in future studies. 
medRxiv preprint doi: https://doi.org/10.1101/2020.10.01.20205229; this version posted October 2, 2020. The copyright holder for this preprint

\section{Introduction}

2 The global spread of coronavirus disease 2019 (COVID-19), first identified in Wuhan, China,

3 in December 2019, has ignited an unprecedented ongoing global pandemic.(1) Although most

4 infected individuals experience only mild symptoms that do not require hospitalization, the

5 absolute number of patients requiring hospital admission is staggering. Risk stratification of

6 these patients is crucial to optimize the use of hospital resources.(2) Several associations with

7 adverse outcomes in COVID-19 patients have been identified, including factors that also

8 predispose to cardiovascular disease (CVD), such as older age, male sex, hypertension,

9 overweight and diabetes.(3,4) Furthermore, individuals with overt CVD appear to be affected

more seriously by COVID-19 infection.(5)

11 The association between cardiovascular events and infectious diseases is well

12 established. Examples include the increased prevalence of myocardial infarction during

13 influenza pandemics,(6) and the higher number of cardiac complications in patients

14 hospitalized for community-acquired pneumonia.(7) However, there are conflicting data

15 whether the presence of shared CVD and COVID-19 risk factors merely reflect advanced age

16 and history of ischemic heart disease in patients who develop severe infection, or are

17 independently associated with adverse outcomes in the COVID-19 patient population. $(4,8)$

18 For example, a higher than expected prevalence of diabetes, hypertension, obesity, and history

19 of CVD was reported during the previous of outbreak Middle East respiratory syndrome

20 coronavirus (MERS-CoV), which shares many similarities with COVID-19.(9)

21 In the present study, we hypothesized that three major risk independent CVD risk

22 factors are associated with adverse outcomes in COVID-19 patients. To this end, we

23 evaluated the time-to-event relationship between COVID-19 disease outcomes and a history

24 of medication use for hypertension, dyslipidemia, and diabetes mellitus in a large prospective

25 Dutch cohort of hospitalized COVID-19 patients. 
medRxiv preprint doi: https://doi.org/10.1101/2020.10.01.20205229; this version posted October 2, 2020. The copyright holder for this preprint

\section{Patients and Methods}

3 Study design

4 COVID-PREDICT is a Dutch multicenter initiative to collect data of hospitalized patients

5 with confirmed COVID-19. For this study, patients from 8 participating hospitals, including

6 two university hospitals were included. All hospitalized patients $>18$ years with a positive

7 COVID-19 polymerase chain reaction (PCR) or high suspicion based on CT-imaging of the

8 thorax were included.(10) A waiver for the use hospital record data was obtained from the

9 Medical Ethical Committees of the participating centers. Patients were given the opportunity

10 to opt out.

11 The collected data was updated with daily reports on vital signs, laboratory results,

12 complications, and clinical outcomes. In addition, the use of antihypertensive, lipid-lowering,

13 and/or antidiabetic medication was determined from the home medication list. These were

14 used as surrogates for hypertension, dyslipidemia, and diabetes. Antihypertensive medication

15 was categorized as using either 0,1 , more than 1 of the following categories: nondihydropyridine calcium channel blockers (CCBs), renin angiotensin system (RAS)-inhibitors

17 (either angiotensin receptor antagonist or angiotensin receptor blockers) and diuretics (either

18 loop diuretics, thiazide or thiazide like diuretics or potassium channel blockers). Lipid-

19 lowering therapy was classified as the use of statin, ezetimibe, fibrates, or PCSK9-inhibitors.

20 Antidiabetic medication was classified as using either 0,1 or more than 1 of the following

21 classes: metformin, sulfonylurea derivates, GLP-1 agonists, DDP4- inhibitors, SGLT-2

22 inhibitors, and insulin. Obesity was defined as a BMI $>30 \mathrm{~kg} / \mathrm{m}$. Smoking was categorized

23 into current or non/former smoker. The combined use of beta-blockers and platelet

24 aggregation inhibitors was used as a surrogate for history of ischemic cardiac disease. 
medRxiv preprint doi: https://doi.org/10.1101/2020.10.01.20205229; this version posted October 2, 2020. The copyright holder for this preprint (which was not certified by peer review) is the author/funder, who has granted medRxiv a license to display the preprint in perpetuity.

It is made available under a CC-BY-ND 4.0 International license .

1 Outcomes were determined 3 and 6 weeks after admission, or earlier when the patient died or

2 was discharged from the hospital.

3

$4 \quad$ Primary and secondary outcomes

5 The primary outcome consisted of overall mortality during the first 21 days following

6 admission. Overall mortality was defined as either mortality during admission or discharge for

7 palliative care, either at home or a palliative care facility. If the patient was discharged alive

8 from the hospital and no further follow-up data was available, we considered the patient to be

9 event free for the whole study period. Secondary outcomes consisted of ICU-admission and

10 mortality in the subset of patients who had been admitted to the ICU.

12 Statistical analysis

13 For the analysis, we included all consecutive patients who were primarily admitted to one of

14 the participating centers between February $27^{\text {th }}$ and July $4^{\text {th }} 2020$. Patients with unknown

15 medication use prior to hospitalization were excluded. Patients were categorized based on the

16 presence of either 0,1 or more than 1 medication based cardiovascular risk factor. Baseline

17 characteristics were depicted as mean \pm standard deviation for normally distributed data,

18 nonnormally as median [interquartile range], or as number (percentage) for categorical

19 variables, and were compared using the appropriate tests (ANOVA, Kruskal-Wallis, chi-

20 squared). The relationship between outcomes and cumulative cardiovascular risk factors was

21 determined using a Kaplan-Meier analysis. We then determined hazard ratios using Cox-

22 regression after correction for age and sex, and with additional correcting for obesity,

23 smoking and history of ischemic cardiac disease. For ICU-mortality, a landmark analysis was

24 performed starting from ICU-admission. Next, with Cox-regression models using the same

25 covariates we determined the association between mortality and the use of antihypertensive, 
medRxiv preprint doi: https://doi.org/10.1101/2020.10.01.20205229; this version posted October 2, 2020. The copyright holder for this preprint (which was not certified by peer review) is the author/funder, who has granted medRxiv a license to display the preprint in perpetuity.

It is made available under a CC-BY-ND 4.0 International license.

1 lipid-lowering, and antidiabetic drugs. All statistical analyses were conducted with $\mathrm{R}$ version

$2 \quad 3.6 .3$ (R Foundation, Vienna, Austria) using the Survival version 3.1-11 and Tableone version

$3 \quad 0.11 .1$ packages.

4

$5 \quad$ Results

6 Patient characteristics

7 Between February $27^{\text {th }} 2020$ and July $4^{\text {th }} 2020$, a total of 1614 patients with a confirmed

8 COVID-19 infection were primarily admitted to one of the participating centers in the

9 Netherlands. After exclusion of patients with an unknown medication list, we included 1604

10 patients in the present analysis. Their mean age was $66 \pm 15$ years, $67.6 \%$ were Caucasian, and

$1160.5 \%$ were men. $6.5 \%$ of the admitted patients were current smokers. The majority of

12 admitted patients $(924,57.6 \%)$ used some form of cardiovascular medication prior to

13 admission. Antihypertensive medication was used by 721 (45.0\%) patients, of whom 497

14 (68.9\%) used RAS-inhibitors, 256 (35.5\%) calcium-antagonists, and 374 (51.9\%) diuretics.

15 Lipid-lowering therapy was used by 557 (34.7\%) patients, predominantly consisting of statins

$16(540,96.9 \%)$. In total, $354(22.1 \%)$ patients used antidiabetic medication, of whom 282

17 (79.7\%) used metformin and 137 patients (38.7\%) insulin. 167 patients (10.4\%) used the

18 combination of a beta-blocker and a platelet aggregation inhibitor, reflecting a history of

19 ischemic cardiac disease. In the subset of 566 patients for whom a more detailed medical

20 history was available, we found a similar prevalence of cardiovascular disease, with $13.1 \%$ of

21 the patients having a history of coronary artery disease, $3.7 \%$ of heart failure, $7.4 \%$ of stroke

22 and $1.6 \%$ of peripheral arterial disease (see Supplement 3). 
medRxiv preprint doi: https://doi.org/10.1101/2020.10.01.20205229; this version posted October 2, 2020. The copyright holder for this preprint (which was not certified by peer review) is the author/funder, who has granted medRxiv a license to display the preprint in perpetuity.

It is made available under a CC-BY-ND 4.0 International license .

\section{Cardiovascular risk factors as markers for mortality and ICU-admission}

2 In the entire cohort, $308(19.2 \%)$ of the patients died or were discharged for palliative care. In

3 total $273(17.0 \%)$ of the patients were admitted to the ICU, of whom 78 died. $1100(68.6 \%)$

4 patients were discharged alive from the hospital, $50(3.1 \%)$ were transferred to another

5 hospital. The remaining patients were still admitted to the hospital at time of the data

6 collection $(126 ; 7.9 \%)$ or follow-up data was not available yet $(20 ; 1.25 \%)$. The Kaplan-Meier

7 analysis showed a significant association between cardiovascular risk factors and overall

8 mortality $(\mathrm{p}<0.0001$; Figure 1A) and a trend towards increased ICU-mortality $(\mathrm{p}=0.055$;

9 Supplement 1). We found no association between cardiovascular risk factors and ICU-

10 admission ( $\mathrm{p}=0.85$; Figure 1B). In Cox-regression analysis, a 5-year age increase was

11 associated with a HR of 1.37 (CI 1.31-1.45) for mortality, while there was no significant

12 association with sex (HR 1.02, CI 0.81-1.28). The presence of two or more cardiovascular risk

13 factors was significantly associated with overall mortality (HR 1.52, 95\%CI 1.15-2.02), but

14 not with ICU-admission or ICU-mortality (Table 2). After additional correction for smoking,

15 obesity, and the combined use of beta-blockers and platelet aggregation inhibitors the

16 presence of two or more risk factors remained associated with mortality (HR 1.38, 95\% CI

$17 \quad 1.02-1.86$, Supplement 2).

Individual risk factors

20 In the Cox-regression models corrected for age and sex, we observed that the use of two or

21 more different classes of antihypertensives and antidiabetics were associated with 21-day

22 mortality, with HR of respectively of 1.46 (95\%CI 1.11-1.91) and 2.09 (95\%CI 1.55-2.80).

23 Similarly, we found a HR of 1.25 (95\%CI 0.99-1.56) for the use of lipid-lowering medication.

24 Additional correction for smoking, obesity and the combined use of beta-blockers and

25 antiplatelet medication attenuated the association between the use of BP-lowering and lipid- 
medRxiv preprint doi: https://doi.org/10.1101/2020.10.01.20205229; this version posted October 2, 2020. The copyright holder for this preprint (which was not certified by peer review) is the author/funder, who has granted medRxiv a license to display the preprint in perpetuity.

It is made available under a CC-BY-ND 4.0 International license .

1 lowering medication towards 1.33 (95\%CI 1.01-1.76) and 1.14 (95\%CI 0.89-1.45) for the use

2 of $\geq 2$ BP-lowering drugs or $\geq 1$ lipid-lowering drug respectively. The association between the

3 use of 2 or more glucose-lowering medications and mortality remained significant with an

4 adjusted HR of 1.93 (95\%CI 1.43-2.62; Supplementary table 2).

\section{Discussion}

7 In a large Dutch cohort of hospitalized COVID-19 patients, we observed that patients with

8 more than one risk factor for CVD had a 52\% higher 3-week mortality risk, independent of

9 age and sex. In addition, our data show that the use of two or more antihypertensives or

10 antidiabetics, or one lipid-lowering drug is associated with adverse outcomes in COVID-19

11 patients. Patients using two or more antidiabetic drugs had the highest mortality risk. This

12 suggests that patients with a history of or at high risk for cardiovascular disease have an

13 increased risk for adverse COVID-19 disease outcomes.

The prevalence of medication use for CVD risk factors was higher in COVID-19 patients than in previously described cohorts representative for the general Dutch population of similar age.(11) Wuhan-based COVID-19 cohorts were the first to describe a higher mortality in those with hypertension and diabetes.(12) However, the average age and reported prevalence of CVD risk factors was much lower in these cohorts than in the present study.(4) The

20 increased case-fatality rate in Europe and the US compared with China may in part be 21 attributable to demographic differences in the COVID-19 infected population.(13) Recent

22 European and US-based cohorts indeed demonstrate a higher average age with a similar

23 distribution of hypertension and diabetes compared to our study, and also show a higher

24 mortality in COVID-19 patients with hypertension and diabetes. $(14,15)$ In line with the

25 results from a large US-based cohort, we observed that age was significantly associated with 
medRxiv preprint doi: https://doi.org/10.1101/2020.10.01.20205229; this version posted October 2, 2020. The copyright holder for this preprint

1 mortality, while we found no significant difference in mortality between sexes.(16) This

2 suggests that although men are more often hospitalized, there is no substantial difference in

3 mortality after admission for severe COVID-19 infection. We add to these findings that the

4 accumulation of CVD risk factors is associated with mortality, independent of age, sex,

5 presence of coronary artery disease, smoking and obesity in hospitalized patients.

7 Analogous to COVID-19, CVD risk factors are also prevalent among patients hospitalized for

8 community-acquired pneumonia.(17) However, we observed a stronger association between

9 hypertension, diabetes, dyslipidemia and mortality in COVID-19 patients compared with

10 previous studies on community-acquired pneumonia, despite a similar prevalence of CVD

11 risk factors.(18) In addition, these effects remained significant after correction for covariates

12 such as smoking, obesity, and the use of beta-blockers and antiplatelet drugs as surrogate for a

13 history of ischemic cardiac disease. This might suggest that CVD risk factors in COVID-19

14 patients disproportionally affect the clinical course of COVID-19 patients compared to other

15 infectious diseases. The present findings are comparable to the previous MERS-CoV

outbreak, which also saw a preponderance of hypertension and diabetes in hospitalized

17 patients.(9) Because both coronaviruses enter the cell through the angiotensin converting enzyme 2 (ACE2) receptor, a hypothesis has become that upregulation of ACE2 in patients

19 with hypertension and/or diabetes facilitates transmission of the virus.(19-22) However,

20 recent studies have shown no association between the use of RAS-medication and the disease

21 course of COVID-19.(23,24) Furthermore, this theory does not explain the increased risk of

22 mortality paired with other CVD risk factors in COVID-19 patients. An alternative

23 explanation is that CVD risk factors predispose to myocardial injury in COVID-19 infected

24 patients, contributing to a more severe clinical course.(25) Two recent studies revealed viral

25 RNA in the myocardium of COVID-19 patients, suggesting that SARS-CoV-2 might infect 
medRxiv preprint doi: https://doi.org/10.1101/2020.10.01.20205229; this version posted October 2, 2020. The copyright holder for this preprint (which was not certified by peer review) is the author/funder, who has granted medRxiv a license to display the preprint in perpetuity.

It is made available under a CC-BY-ND 4.0 International license .

1 the heart directly. It can be speculated that those with (pre-clinical) atherosclerosis are prone

2 to experience coronary ischemia from viral myocardial involvement.(26,27)

3

4 In our cohort of COVID-19 patients, the presence of diabetes had the strongest association

5 with mortality and remained significant after correction for covariates such as smoking,

6 obesity, and the use of beta-blockers and antiplatelet drugs as surrogate for coronary artery

7 disease. We observed smaller effect sizes for the presence of hypertension and dyslipidemia.

8 These findings might suggest that diabetes predisposes for adverse outcomes in COVID-19

9 patients not only through its association with CVD, but potentially via other

10 pathophysiological pathways specific to diabetes. A recent Chinese cohort showed diabetes to

11 be associated with higher ICU-admission and more in-hospital mortality, but not

12 independently of hypertension and history of CVD.(8) Interestingly, in those with diabetes,

13 hypertension was associated with in-hospital death, independently of history of CVD, further

14 supporting the additive effect of CVD risk factors on COVID-19 mortality. Nevertheless, it is

15 hard to disentangle the precise relation based on epidemiological data. In line with current

guidelines on CVD risk management, cardiovascular medication from different classes were

17 often prescribed together in our cohort, also in patients with diabetes.(28) This makes it

18 difficult to assess their separate contribution to mortality. It remains, therefore, unknown

19 whether diabetes alone is associated with a higher risk of adverse outcomes or whether it is

20 merely a reflection of increased vascular ageing in combination with the other risk

21 factors.(29) In contrast to our results, the recent cohort of Cummings et al, found that among

22 cardiovascular risk factors, only chronic cardiac disease was a strong predictor for hospital

23 mortality, while smaller associations were found for other risk factors, including diabetes.(16)

24 In line, a recent Italian cohort of hospitalized COVID-19 patients showed an increased

25 prevalence of hypertension and diabetes amongst non-survivors, but only diabetes was an 
medRxiv preprint doi: https://doi.org/10.1101/2020.10.01.20205229; this version posted October 2, 2020. The copyright holder for this preprint

1 independent predictor after correction for other comorbidities.(30) In the present study, the

2 cumulative presence of CVD risk factors did not show an association with increased risk for

3 ICU-admission. This may have been influenced by selection prior to ICU admission, where

4 the presence of co-morbidity was taken into account in the shared decision-making process,

5 leading to a relative underrepresentation of patients with CV-risk factors.

7 The present analysis has several limitations. First, data collection was based on data collection

8 forms of the WHO, which did not include detailed information on cardiovascular disease

9 history. For this reason, we relied on medication use as a surrogate marker for established

10 cardiovascular risk factors or disease, which has been used before in big cohort studies.(31)

11 Nevertheless, some of these drugs might have been prescribed for different indications.

12 Secondly, we only obtained follow-up during the first 21 days, however as depicted in the

13 Kaplan-Meier analysis, almost all events occurred during the first 14 days, in line with earlier

14 descriptions.(4) Finally, we cannot exclude that mortality in the current study is partially

15 caused by other factors than COVID-19. However, as we used 21-day mortality as our

16 primary outcome and only included patients admitted to the hospital with confirmed COVID-

1719 infection, it is very likely that the majority of deaths were directly attributable to COVID-

1819.

20 In conclusion, the accumulation of CVD risk factors leads to a stepwise increased risk for

21 short-term mortality in hospitalized COVID-19 patients. Patients with diabetes had the

22 highest risk, followed by similar risks for hypertension and dyslipidemia. Mechanistic studies

23 investigating how CVD risk factors disproportionately affect COVID-19 patients compared to

24 other infectious diseases are warranted. 
medRxiv preprint doi: https://doi.org/10.1101/2020.10.01.20205229; this version posted October 2, 2020. The copyright holder for this preprint

(which was not certified by peer review) is the author/funder, who has granted medRxiv a license to display the preprint in perpetuity.

It is made available under a CC-BY-ND 4.0 International license.

\section{Acknowledgements}

2 We would like to thank the CovidPredict consortium (www.covidpredict.org) for their efforts

3 in providing the patient data.

4

\section{Author contributions}

6 DC, NN, YK, LR, ES, BjvdB, LV, MB, PE conceptualized and designed the study. DC, NN,

7 YK, LR performed the data analysis. DC, NN, YK, ES, BjvdB drafted the manuscript.

8 All authors have made substantial contributions to the following: (1) the conception and

9 design of the study, or acquisition of data, or analysis and interpretation of data, (2) revising

10 the manuscript critically for important intellectual content, (3) final approval of the version to

11 be submitted.

12

\section{Funding}

14 DC is supported by a ZonMW grant (project number: 10430022010002).

15

16 Competing interests

17 N.S.N. and L.F.R. are co-founders of Lipid Tools. E.S.G.S. reports personal fees from

18 Amgen, personal fees from Sanofi-Regeneron, personal fees from Esperion, grants from

19 Athera, outside the submitted work.

20 
medRxiv preprint doi: https://doi.org/10.1101/2020.10.01.20205229; this version posted October 2, 2020. The copyright holder for this preprint (which was not certified by peer review) is the author/funder, who has granted medRxiv a license to display the preprint in perpetuity.

It is made available under a CC-BY-ND 4.0 International license .

\section{References}

2 1. World Health Organization. Coronavirus disease 2019 (COVID-19), situation report 392.

4 2. Lipsitch M, Swerdlow DL, Finelli L. Defining the Epidemiology of Covid-19 - Studies

$5 \quad$ Needed. N Engl J Med. 2020 Mar;382(13):1194-6.

6 3. Wilkins JT, Ning H, Berry J, Zhao L, Dyer AR, Lloyd-Jones DM. Lifetime risk and 7 years lived free of total cardiovascular disease. JAMA. 2012;308(17):1795-801.

8 4. Zhou F, Yu T, Du R, Fan G, Liu Y, Liu Z, et al. Clinical course and risk factors for 9 mortality of adult inpatients with COVID-19 in Wuhan, China: a retrospective cohort study. Lancet. 2020;

11 5. Zheng YY, Ma YT, Zhang JY, Xie X. COVID-19 and the cardiovascaular system. Nat Rev Cardiol. 2020 Mar;17:259-60.

6. Nguyen JL, Yang W, Ito K, Matte TD, Shaman J, Kinney PL. Seasonal influenza infections and cardiovascular disease mortality. JAMA Cardiol. 2016 Jun;1(3):274-81. complications in patients with community-acquired pneumonia incidence, timing, risk factors, and association with short-term mortality. Circulation. 2012 Feb;125(6):77381.

8. Shi Q, Zhang X, Jiang F, Zhang X, Hu N, Bimu C, et al. Clinical Characteristics and Risk Factors for Mortality of COVID-19 Patients With Diabetes in Wuhan, China: A Two-Center, Retrospective Study. Diabetes Care. 2020;43(7):1382-91.

22 9. Badawi A, Ryoo SG. Prevalence of comorbidities in the Middle East respiratory syndrome coronavirus (MERS-CoV): a systematic review and meta-analysis. Int J Infect Dis. 2016 Aug;49:129-33. 
medRxiv preprint doi: https://doi.org/10.1101/2020.10.01.20205229; this version posted October 2, 2020. The copyright holder for this preprint

1 radiologists in differentiating COVID-19 from viral pneumonia on chest CT.

$2 \quad$ Radiology. 2020;200823.

3 11. van Laer SD, Snijder MB, Agyemang C, Peters RJG, van den Born BJH. Ethnic differences in hypertension prevalence and contributing determinants - the HELIUS study. Eur J Prev Cardiol. 2018;25(18):1914-22.

6 12. Guan WJ, Ni ZY, Hu Y, Liang WH, Ou CQ, He JX, et al. Clinical Characteristics of Coronavirus Disease 2019 in China. N Engl J Med. 2020;1-13.

8 13. Onder G, Rezza G, Brusaferro S. Case-Fatality Rate and Characteristics of Patients

Dying in Relation to COVID-19 in Italy. JAMA - J Am Med Assoc. 2020;2019:2019-

14. Richardson S, Hirsch JS, Narasimhan M, Crawford JM, McGinn T, Davidson KW, et

15. Goyal P, Choi JJ, Pinheiro LC, Schenck EJ, Chen R, Jabri A, et al. Clinical Characteristics of Covid-19 in New York City. N Engl J Med. 2020 Apr 17;

16. Cummings MJ, Baldwin MR, Abrams D, Jacobson SD, Meyer BJ, Balough EM, et al. Epidemiology, clinical course, and outcomes of critically ill adults with COVID-19 in New York City: a prospective cohort study. Lancet [Internet]. 2020;S01406736(20)31189-2. Available from: http://dx.doi.org/10.1016/S0140-6736(20)31189-2

17. Corrales-Medina VF, Musher DM, Shachkina S, Chirinos JA. Acute pneumonia and the cardiovascular system. Lancet. 2013;381(9865):496-505.

18. Violi F, Cangemi R, Falcone M, Taliani G, Pieralli F, Vannucchi V, et al. pneumonia. Clin Infect Dis. 2017;64(11):1486-93.

19. Fang L, Karakiulakis G, Roth M. Are patients with hypertension and diabetes mellitus 
medRxiv preprint doi: https://doi.org/10.1101/2020.10.01.20205229; this version posted October 2, 2020. The copyright holder for this preprint (which was not certified by peer review) is the author/funder, who has granted medRxiv a license to display the preprint in perpetuity. It is made available under a CC-BY-ND 4.0 International license .

$1 \quad$ at increased risk for COVID-19 infection? Lancet Respir Med. 2020 Apr;8(4):e21.

2 20. Vaduganathan M, Vardeny O, Michel T, McMurray JJ V, Pfeffer MA, Solomon SD. Renin-Angiotensin-Aldosterone System Inhibitors in Patients with Covid-19. N Engl J Med. 2020 Mar;

5 21. Kuster GM, Pfister O, Burkard T, Zhou Q, Twerenbold R, Haaf P, et al. SARS-CoV2: should inhibitors of the renin-angiotensin system be withdrawn in patients with COVID-19? Eur Heart J. 2020 Mar;

8 22. Danser AHHJ, Epstein M, Batlle D. Renin-Angiotensin System Blockers and the COVID-19 Pandemic: At Present There Is No Evidence to Abandon ReninAngiotensin System Blockers. Hypertension. 2020 Mar; 
medRxiv preprint doi: https://doi.org/10.1101/2020.10.01.20205229; this version posted October 2, 2020. The copyright holder for this preprint

(which was not certified by peer review) is the author/funder, who has granted medRxiv a license to display the preprint in perpetuity.

It is made available under a CC-BY-ND 4.0 International license.

1

2 28. The Task Force for the management of arterial hypertension of the European Society of

2020;323(24):2518-20.

Cardiology (ESC) and the European Society of Hypertension (ESH). 2018 ESC/ESH

Guidelines for the management of arterial hypertension. Eur Heart J. 2018 Aug 25;39(33):3021-104.

29. Ungvari Z, Tarantini S, Donato AJ, Galvan V, Csiszar A. Mechanisms of vascular aging. Circ Res. 2018;123(7):849-67.

30. Iaccarino G, Grassi G, Borghi C, Ferri C, Salvetti M, Volpe M. Age and Multimorbidity Predict Death Among COVID-19 Patients: Results of the SARS-RAS Study of the Italian Society of Hypertension. Hypertens (Dallas, Tex 1979). 2020;76(2):366-72.

31. Attaei MW, Khatib R, McKee M, Lear S, Dagenais G, Igumbor EU, et al. Availability and affordability of blood pressure-lowering medicines and the effect on blood pressure control in high-income, middle-income, and low-income countries: an analysis of the PURE study data. Lancet Public Heal. 2017;2(9):e411-9. 
medRxiv preprint doi: https://doi.org/10.1101/2020.10.01.20205229; this version posted October 2, 2020. The copyright holder for this preprint (which was not certified by peer review) is the author/funder, who has granted medRxiv a license to display the preprint in perpetuity.

It is made available under a CC-BY-ND 4.0 International license.

1 Figure 1. Survival and time-to event analysis of cumulative cardiovascular risk factors

\section{2 on mortality and ICU-admission}
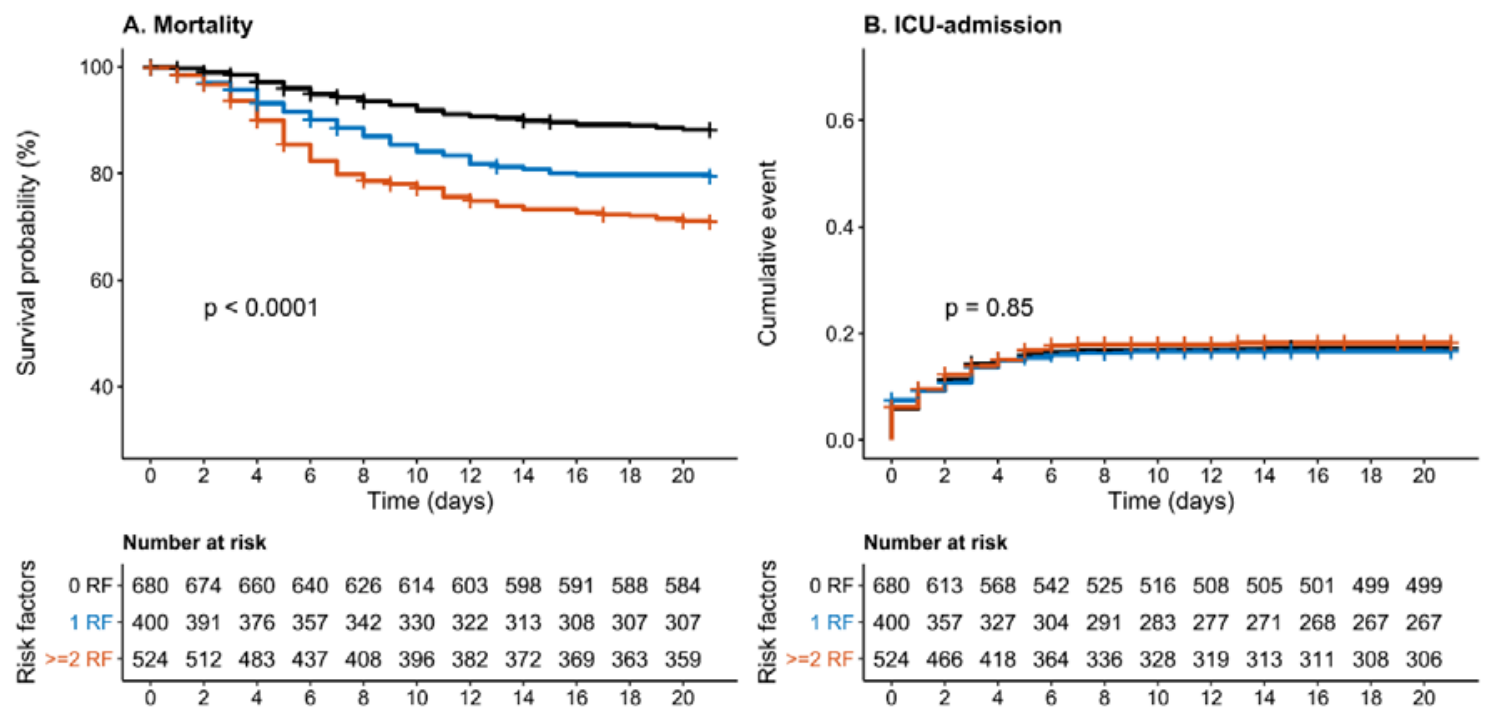

3

4 Kaplan-Meier analysis of hypertension, dyslipidemia and diabetes stratified into 0, 1 or more

5 risk factors versus adverse clinical outcomes. Left panel (A) depicts mortality, right panel (B)

6 ICU-admission. Log-rank test was used to test for differences between curves. RF, risk factor;

7 ICU, intensive care unit. 
medRxiv preprint doi: https://doi.org/10.1101/2020.10.01.20205229; this version posted October 2, 2020. The copyright holder for this preprint (which was not certified by peer review) is the author/funder, who has granted medRxiv a license to display the preprint in perpetuity.

It is made available under a CC-BY-ND 4.0 International license .

1 Table 1. Baseline characteristics

\begin{tabular}{|c|c|c|c|c|c|}
\hline & Overall & O RF & $1 \mathrm{RF}$ & $\geq 2 \mathrm{RF}$ & $p$ \\
\hline$n$ & 1604 & 680 & 400 & 524 & \\
\hline Age (mean (SD)) & $65.67(15.06)$ & $58.59(15.71)$ & $69.93(13.01)$ & $\begin{array}{r}71.62 \\
(11.45)\end{array}$ & $<0.001$ \\
\hline Women & $633(39.5)$ & $298(43.8)$ & $170(42.5)$ & $165(31.5)$ & $<0.001$ \\
\hline Chronic cardiac disease & $467(29.2)$ & $71(10.5)$ & $117(29.3)$ & $279(53.4)$ & $<0.001$ \\
\hline Hypertension & $734(46.0)$ & $80(11.8)$ & $242(60.8)$ & $412(78.8)$ & $<0.001$ \\
\hline $\begin{array}{l}\text { Chronic pulmonary } \\
\text { disease }\end{array}$ & $288(18.0)$ & $92(13.6)$ & $82(20.6)$ & $114(21.9)$ & $<0.001$ \\
\hline Asthma & $179(11.2)$ & $77(11.4)$ & $41(10.3)$ & $61(11.7)$ & 0.793 \\
\hline Chronic kidney disease & $150(9.4)$ & $17(2.5)$ & $48(12.0)$ & $85(16.3)$ & $<0.001$ \\
\hline Diabetes & $411(25.7)$ & $19(2.8)$ & $66(16.5)$ & $326(62.3)$ & $<0.001$ \\
\hline Malignant neoplasm & $98(6.2)$ & $36(5.3)$ & $25(6.3)$ & $37(7.1)$ & 0.455 \\
\hline $\begin{array}{l}\text { Chronic hematologic } \\
\text { disorder }\end{array}$ & $57(3.6)$ & $32(4.7)$ & $11(2.8)$ & $14(2.7)$ & 0.1 \\
\hline Smoking & $78(6.5)$ & $30(6.0)$ & $16(5.4)$ & $32(7.8)$ & 0.383 \\
\hline Obesity & $464(30.8)$ & $164(26.1)$ & $112(29.4)$ & $188(37.8)$ & $<0.001$ \\
\hline $\begin{array}{l}\text { Combined use of beta- } \\
\text { blockers and antiplatelet } \\
\text { drugs }\end{array}$ & $167(10.4)$ & $7(1.0)$ & $35(8.8)$ & $125(23.9)$ & $<0.001$ \\
\hline Antihypertensive-Rx & & & & & $<0.001$ \\
\hline 0 & $883(55.0)$ & $680(100.0)$ & $145(36.2)$ & $58(11.1)$ & \\
\hline 1 & $377(23.5)$ & $0(0.0)$ & $141(35.2)$ & $236(45.0)$ & \\
\hline 2 & $282(17.6)$ & $0(0.0)$ & $95(23.8)$ & $187(35.7)$ & \\
\hline$\geq 3$ & $62(3.9)$ & $0(0.0)$ & $19(4.8)$ & $43(8.2)$ & \\
\hline Lipid-lowering-Rx & & & & & $<0.001$ \\
\hline 0 & $1047(65.3)$ & $0(0.0)$ & $296(74.0)$ & $89(13.5)$ & \\
\hline$\geq 1$ & $557(34.7)$ & $0(0.0)$ & $104(26.0)$ & $453(86.5)$ & \\
\hline Glucose-lowering- $\mathrm{Rx}$ & & & & & $<0.001$ \\
\hline 0 & $1250(77.9)$ & $680(100.0)$ & $359(89.8)$ & $211(40.3)$ & \\
\hline 1 & $170(10.6)$ & $0(0.0)$ & $23(5.8)$ & $147(28.1)$ & \\
\hline$\geq 2$ & $184(11.5)$ & $0(0.0)$ & $18(4.5)$ & $166(31.7)$ & \\
\hline
\end{tabular}

2

3 RF, risk factor; SD, standard deviation; IQR, interquartile range; Rx, medication. P-values

4 indicate comparison between subgroups based on the presence of cumulative risk factors. 
medRxiv preprint doi: https://doi.org/10.1101/2020.10.01.20205229; this version posted October 2, 2020. The copyright holder for this preprint (which was not certified by peer review) is the author/funder, who has granted medRxiv a license to display the preprint in perpetuity. It is made available under a CC-BY-ND 4.0 International license.

1 Table 2. Effect of cumulative cardiovascular risk factors on primary and secondary outcomes 2

3

\begin{tabular}{c|l|rrr|r} 
& Cumulative risk factors & HR & $95 \% \mathrm{Cl}$ & & $\mathbf{p}$ \\
\hline \multirow{3}{*}{ Mortality } & $0 \mathrm{RF}$ & 1 (ref) & & & \\
& $1 \mathrm{RF}$ & 1.04 & 0.76 & 1.43 & 0.786 \\
& $\geq 2 \mathrm{RF}$ & 1.52 & 1.15 & 2.02 & 0.004 \\
\hline \multirow{4}{*}{ ICU admission } & $0 \mathrm{RF}$ & 1 (ref) & & & \\
& $1 \mathrm{RF}$ & 1.11 & 0.80 & 1.53 & 0.534 \\
& $\geq 2 \mathrm{RF}$ & 1.15 & 0.85 & 1.56 & 0.355 \\
\hline \multirow{3}{*}{ ICU-mortality } & $0 \mathrm{RF}$ & $1(\mathrm{ref})$ & & & \\
& $1 \mathrm{RF}$ & 0.86 & 0.46 & 1.60 & 0.625 \\
& $\geq 2 \mathrm{RF}$ & 1.52 & 0.90 & 2.55 & 0.115 \\
\hline
\end{tabular}

4

5 Cox-regression for the effect of cumulative cardiovascular risk factors on mortality, ICU-

6 admission and ICU-mortality, corrected for sex and age. HR, hazard ratio; CI, confidence

7 interval; ICU, intensive care unit.

8 
medRxiv preprint doi: https://doi.org/10.1101/2020.10.01.20205229; this version posted October 2, 2020. The copyright holder for this preprint (which was not certified by peer review) is the author/funder, who has granted medRxiv a license to display the preprint in perpetuity.

It is made available under a CC-BY-ND 4.0 International license .

1 Table 3. Effect of antihypertensive, lipid-lowering, and antidiabetic medications on

2 mortality

3

\begin{tabular}{l|rrrr} 
Mortality & HR & 95\%Cl & \multicolumn{2}{c}{$\mathbf{p}$} \\
\hline 0 antihypertensive-Rx & 1 (ref) & & & \\
1 antihypertensive-Rx & 1.08 & 0.81 & 1.43 & 0.597 \\
$\geq 2$ antihypertensive-Rx & 1.46 & 1.11 & 1.91 & 0.006 \\
\hline 0 lipid-lowering- $\mathrm{Rx}$ & 1 (ref) & & & \\
$\geq 1$ lipid-lowering-Rx & 1.25 & 0.99 & 1.56 & 0.058 \\
\hline 0 antidiabetic-Rx & 1 (ref) & & & \\
1 antidiabetic- $\mathrm{Rx}$ & 1.34 & 0.97 & 1.85 & 0.077 \\
$\geq 2$ antidiabetic- $\mathrm{Rx}$ & 2.09 & 1.55 & 2.80 & $<0.001$ \\
\hline
\end{tabular}

4

5

6 Cox-regression for the effect of the number of antihypertensive, lipid-lowering and

7 antidiabetic drug classes on mortality, with correction for age and sex. Rx, medication; HR,

8 hazard ratio; CI, confidence interval.

9 


\section{Supplement 1. Survival analysis for ICU-mortality}

2 Figure S1. Survival analysis of cumulative cardiovascular risk factors for ICU-mortality
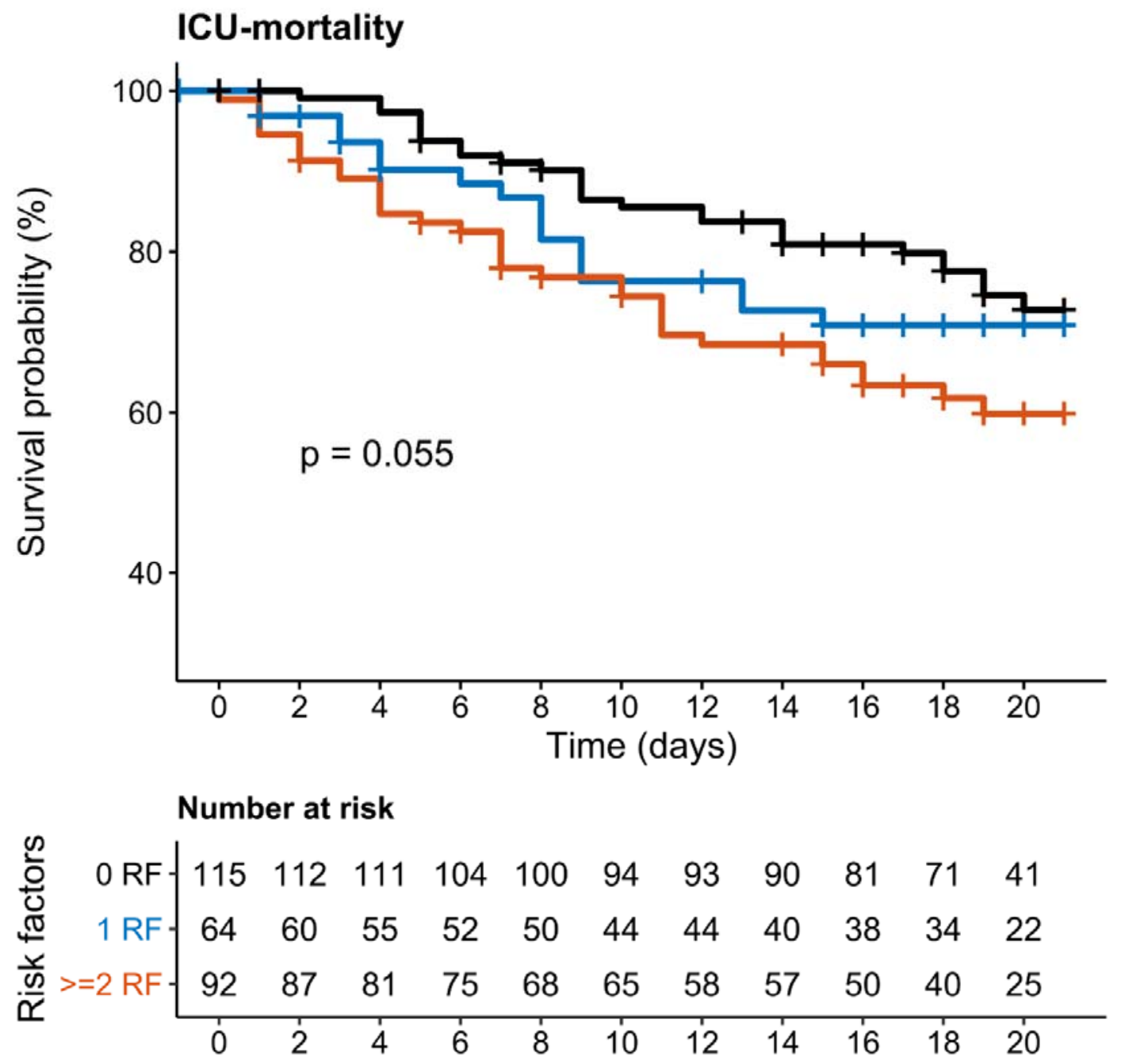

3

4 Kaplan-Meier analysis of hypertension, dyslipidemia and diabetes stratified into 0, 1 or more

5 risk factors versus adverse clinical outcomes for mortality in patients admitted to the ICU.

6 Log-rank test was used to test for differences between curves. RF, risk factor; ICU, intensive

7 care unit. 
medRxiv preprint doi: https://doi.org/10.1101/2020.10.01.20205229; this version posted October 2, 2020. The copyright holder for this preprint

(which was not certified by peer review) is the author/funder, who has granted medRxiv a license to display the preprint in perpetuity.

It is made available under a CC-BY-ND 4.0 International license.

1 Supplement 2: Cox-regression models with additional correction for smoking, obesity

2 and the use of both a beta-blocker and antiplatelet drug.

3

4 We performed an additional analysis for the association between the cardiovascular risk

5 factors and mortality with correction for smoking, obesity and the use of both a beta-blocker

6 and antiplatelet drug. Data for smoking status was missing for $22.7 \%$ of the patients, data for

7 obesity was missing for $9.2 \%$ of the patients. Imputation for these covariates was performed

8 using the Multivariate Imputation by Chained (mice) package version 3.8.0. The pooled

9 results averaged over 25 iterations are depicted in Supplementary Table 2. A complete cases

10 analysis showed similar results (data not shown). 
Supplementary table S1: Effect of the cumulative risk factors, antihypertensive medication, lipid-lowering medication and antidiabetic medication on mortality after correction for covariates.

\begin{tabular}{|c|c|c|c|c|}
\hline \multirow{2}{*}{ Covariate } & \multicolumn{4}{|c|}{ Mortality } \\
\hline & HR & $95^{\circ}$ & & P-value \\
\hline 1 RF & 1.01 & 0.73 & 1.39 & 0.956 \\
\hline$\geq 2 \mathrm{RF}$ & 1.38 & 1.02 & 1.86 & 0.034 \\
\hline Women & 0.94 & 0.74 & 1.19 & 0.612 \\
\hline Age & 1.07 & 1.06 & 1.08 & $<0.001$ \\
\hline $\begin{array}{l}\text { Beta-blockers and } \\
\text { antiplatelet-Rx }\end{array}$ & 1.27 & 0.93 & 1.73 & 0.130 \\
\hline Obesity & 1.26 & 0.97 & 1.65 & 0.086 \\
\hline Current smoker & 0.83 & 0.46 & 1.50 & 0.533 \\
\hline
\end{tabular}

\begin{tabular}{|c|c|c|c|c|c|c|c|c|c|c|c|c|c|c|}
\hline \multirow{3}{*}{$\begin{array}{l}\text { Covariate } \\
1 \text { BP-lowering-Rx }\end{array}$} & \multicolumn{4}{|c|}{ Mortality } & \multirow{4}{*}{\begin{tabular}{|l} 
Covariate \\
1 lipid-lowering-Rx
\end{tabular}} & \multicolumn{4}{|c|}{ Mortality } & \multirow{3}{*}{\begin{tabular}{|l|} 
Covariate \\
1 antidiabetic-Rx
\end{tabular}} & \multicolumn{4}{|c|}{ Mortality } \\
\hline & \multirow{2}{*}{\begin{tabular}{|l} 
HR \\
1.04
\end{tabular}} & \multicolumn{2}{|c|}{$95 \% \mathrm{Cl}$} & P-value & & \multirow{2}{*}{$\begin{array}{l}\mathrm{HR} \\
1.14\end{array}$} & \multicolumn{2}{|c|}{$95 \% \mathrm{Cl}$} & \multirow{2}{*}{ P-value } & & \multirow{2}{*}{$\begin{array}{l}\mathrm{HR} \\
1.25\end{array}$} & \multicolumn{2}{|c|}{$95 \% \mathrm{Cl}$} & \multirow{2}{*}{$\begin{array}{r}\text { P-value } \\
0.182\end{array}$} \\
\hline & & 0.78 & 1.38 & 0.790 & & & 0.89 & 1.45 & & & & 0.90 & 1.74 & \\
\hline$\geq 2$ BP-lowering-Rx & 1.33 & 1.01 & 1.76 & 0.043 & & & & & & $\geq 2$ antidiabetic- $\mathbf{R x}$ & 1.93 & 1.43 & 2.62 & $<0.001$ \\
\hline Women & 0.90 & 0.72 & 1.14 & 0.391 & Women & 0.92 & 0.73 & 1.17 & 0.502 & Women & 0.93 & 0.74 & 1.17 & 0.538 \\
\hline Age & 1.07 & 1.06 & 1.08 & $<0.001$ & Age & 1.07 & 1.06 & 1.08 & $<0.001$ & Age & 1.07 & 1.06 & 1.08 & $<0.001$ \\
\hline $\begin{array}{l}\text { Beta-blockers and } \\
\text { antiplatelet-Rx }\end{array}$ & 1.34 & 0.99 & 1.82 & 0.056 & $\begin{array}{l}\text { Beta-blockers and } \\
\text { antiplatelet-Rx }\end{array}$ & 1.36 & 1.00 & 1.86 & 0.051 & $\begin{array}{l}\text { Beta-blockers and } \\
\text { antiplatelet-Rx }\end{array}$ & 1.34 & 0.99 & 1.80 & 0.057 \\
\hline Obesity & 1.27 & 0.97 & 1.66 & 0.078 & Obesity & 1.30 & 1.00 & 1.69 & 0.051 & Obesity & 1.18 & 0.90 & 1.55 & 0.226 \\
\hline Current smoker & 0.87 & 0.50 & 1.51 & 0.615 & Current smoker & 0.87 & 0.50 & 1.52 & 0.624 & Current smoker & 0.91 & 0.52 & 1.58 & 0.725 \\
\hline
\end{tabular}


Cox-regression for the effect of the number of antihypertensive, lipid-lowering and antidiabetic drug classes on mortality. Table depicts results from multivariate analysis including age, sex, obesity, current smoker and the use of beta-blockers and antiplatelet medication. Rx, medication; HR, hazard ratio; CI, confidence interval. 
medRxiv preprint doi: https://doi.org/10.1101/2020.10.01.20205229; this version posted October 2, 2020. The copyright holder for this preprint (which was not certified by peer review) is the author/funder, who has granted medRxiv a license to display the preprint in perpetuity.

It is made available under a CC-BY-ND 4.0 International license .

\section{Supplement 3: Baseline characteristics in subset with detailed clinical history}

In three of the participating hospitals (Amsterdam UMC location AMC, Amsterdam UMC

location VUMC, Flevoziekenhuis), we collected additional clinical information to validate the medication use as surrogate marker for cardiovascular risk factors and disease. 
medRxiv preprint doi: https://doi.org/10.1101/2020.10.01.20205229; this version posted October 2, 2020. The copyright holder for this preprint (which was not certified by peer review) is the author/funder, who has granted medRxiv a license to display the preprint in perpetuity.

It is made available under a CC-BY-ND 4.0 International license.

Supplementary table S2: Baseline characteristics of complete cohort, and subgroup where additional information about prior cardiovascular events was available.

\begin{tabular}{|c|c|c|}
\hline $\mathrm{n}$ & $\begin{array}{r}\text { Overall } \\
1604 \\
\end{array}$ & $\begin{array}{r}\text { Subset } \\
566 \\
\end{array}$ \\
\hline Age (mean (SD)) & $65.67(15.06)$ & $61.37(14.60)$ \\
\hline Women & $633(39.5)$ & $241(42.6)$ \\
\hline Chronic cardiac disease & $467(29.2)$ & $125(22.1)$ \\
\hline Hypertension & $734(46.0)$ & $252(44.8)$ \\
\hline Chronic pulmonary disease & $288(18.0)$ & $77(13.6)$ \\
\hline Asthma & $179(11.2)$ & $56(9.9)$ \\
\hline Chronic kidney disease & $150(9.4)$ & $57(10.1)$ \\
\hline Diabetes & $411(25.7)$ & $154(27.2)$ \\
\hline Malignant neoplasm & $98(6.2)$ & $31(5.5)$ \\
\hline Chronic hematologic disorder & $57(3.6)$ & $23(4.1)$ \\
\hline Smoking & $78(6.5)$ & $28(6.2)$ \\
\hline Obesity & $464(30.8)$ & $168(32.8)$ \\
\hline $\begin{array}{l}\text { Combined use of beta-blockers and } \\
\text { antiplatelet drugs }\end{array}$ & $167(10.4)$ & $50(8.8)$ \\
\hline History of coronary artery disease & & $74(13.1)$ \\
\hline History of heart failure & & $21(3.7)$ \\
\hline History of stroke & & $42(7.4)$ \\
\hline History of peripheral artery disease & & $9(1.6)$ \\
\hline \multicolumn{3}{|l|}{ Antihypertensive- $\mathrm{Rx}$} \\
\hline 0 & $883(55.0)$ & $327(57.8)$ \\
\hline 1 & $377(23.5)$ & $126(22.3)$ \\
\hline 2 & $282(17.6)$ & $81(14.3)$ \\
\hline$\geq 3$ & $62(3.9)$ & $32(5.7)$ \\
\hline \multicolumn{3}{|l|}{ Lipid-lowering-Rx } \\
\hline 0 & $1047(65.3)$ & $399(70.5)$ \\
\hline$\geq 1$ & $557(34.7)$ & $167(29.5)$ \\
\hline \multicolumn{3}{|l|}{ Glucose-lowering- $R x$} \\
\hline 0 & $1250(77.9)$ & 435 (76.9) \\
\hline 1 & $170(10.6)$ & $60(10.6)$ \\
\hline$\geq 2$ & $184(11.5)$ & $71(12.5)$ \\
\hline
\end{tabular}

$\mathrm{RF}$, risk factor; $\mathrm{SD}$, standard deviation; IQR, interquartile range, Rx medication. 